\title{
Political celebrities and elite politics in contemporary China
}

\author{
Elaine Jeffreys \\ University of Technology Sydney, Australia
}

Corresponding author: Elaine Jeffreys, School of International Studies, Faculty of Arts and Social Sciences, University of Technology Sydney, P.O. Box 123, Broadway NSW 2007, Australia Email: elaine.jeffreys@uts.edu.au

\begin{abstract}
This article examines the rise of celebrity politics in mainland China. It outlines some typologies of Western celebrity politics and considers whether equivalent forms exist in China. It then examines the rise of Chinese politician celebrities and celebrity involvement in the National People's Congress and the Chinese People's Political Consultative Conference. An examination of celebrity participation in these forums shows that celebrity politics in China chiefly functions to support government policies, but also reveals a broadening of elite networks and the capacity of those networks to generate public discussion of alternative policies and politics. Rather than supporting claims that celebrity politics is spectacular or theatrical, it demonstrates instead the connections between celebrity and mundane aspects of Chinese governance.
\end{abstract}

Keywords: celebrity politicians, elites, National People's Congress, Chinese People's Political Consultative Conference, politics

Celebrity politics is a growing area of popular and academic attention. Besides the apparent upsurge of commentary on celebrity and politics in tabloids, gossip magazines, business magazines, and social networking sites, there are now numerous academic texts on celebrity politics and activism in the context of Western societies. ${ }^{1}$ Celebrity politics refers to the celebritization of politicians through marketing communication strategies designed to brand their political personas, leadership style and policies, and the increasing involvement of 'high-visibility figures from traditionally non-political spheres', such as entertainment, arts and sports, in political arenas. ${ }^{2}$ This definition excludes corporate CEOs because political, corporate and military leaders comprise the traditional 'power elite' of Western societies; it focuses analysis instead on the different links that are emerging between politics and entertainment stars.

The growth of celebrity politics has met with mixed responses. Most scholars are critical, concluding that celebrity politics undermines democratic governance by trivializing politics and 
turning it into 'theatre', or entrenching 'spin' politics, duping voters, and giving non-expert elites undue power and influence. ${ }^{3}$ Other scholars suggest that it may help to broaden elite structures, act as a potential check on executive power, and engage people in politics who might not otherwise be interested. ${ }^{4}$ Whichever the case may be, such comments typically refer to the growth of celebrity politics in Western liberal democracies.

This article examines the emerging links between celebrity and politics in the People's Republic of China (PRC). It thus differs notably from the existing literature by examining celebrity politics in the context of a non-democratic, authoritarian state. The term 'PRC' is used to refer to post1949 mainland China. The article does not examine celebrity politics in Hong Kong and Macao.

Celebrity politics may seem a contradiction in terms in a country with one ruling political party - the Chinese Communist Party (CCP). The system of one-party rule precludes the existence of effective opposition political parties and civil society organizations as they are understood in Western societies, thereby removing the need for mediatized political competition - a perceived major driver of the contemporary celebritization of politics. ${ }^{5}$ The PRC also has a history of strict media controls, and only began to develop a consumer society and celebrity culture after adopting a policy of marketbased economic reforms, and opening up to the rest of the world, in December 1978. Thus, as with private entrepreneurs, the emergence of commercial entertainment and sports stars as a stratum of elites in China is a relatively recent phenomenon. ${ }^{6}$

Nonetheless, celebrity has entered the terrain of governance in the PRC along with the growth of commercial popular culture, the loosening of political controls over the broadcast media, and the development of the Chinese Internet and social media. Some Chinese politicians have become celebrities, either intentionally or by accident, along with the branding of their leadership styles. Celebrities from the fields of commercial entertainment, arts, and sports have also participated in the National People's Congress (NPC), which is the PRC's legislature, and the Chinese People's Political Consultative Conference (CPPCC), which acts in theory as the 'watchdog of the country's governance' by advising the NPC on central and local government policy; the NPC and CPPCC were formed in 1954 and 1949 respectively. ${ }^{7}$ The NPC and the CPPCC are widely viewed as 'rubber-stamp organizations' for CCP decisions. ${ }^{8}$ However, the NPC with nearly 3000 elected delegates offers the only large-scale elite political institution in mainland China with a process remotely approaching 'democratic representation and participation' - the only other outlet being village elections. Likewise, although its membership of over 2000 delegates is nominated by the state, the CPPCC is the only institutionalized forum in mainland China that provides 'a voice' for groups and individuals outside of the ruling CCP. Indeed, the nomination of Yao Ming, formerly a star player with the US National Basketball Association, to the Shanghai committee of the CPPCC in January 2012, where he advocates for sports education and charity, has led one reporter to declare that 'Yao Ming is China's newest popular, controversial celebrity politician'. 
By examining the celebritization of politics and the politicization of celebrity in China, this article contributes to the literature on celebrity politics and to studies of elite political participation in contemporary China. The latter literature has focused on the political participation of economic elites from the private corporate sector since the 2000s and has not considered commercial entertainment and sports stars as part of China's emerging stratum of newly rich elites with potential political influence. ${ }^{10}$ To do so, the article first outlines some typologies of Western celebrity politics and considers whether equivalent forms can be found in the PRC. It then examines the rise of politician celebrities in China and the nature of celebrity participation at the 11th NPC and CPPCC (2008-12). I conclude that the growth of celebrity politics in China chiefly functions to support and augment government policies, but it also demonstrates a broadening of elite networks and the capacity of those networks to generate public discussion of alternative policies and politics. Moreover, an examination of celebrity involvement in the political spaces of the NPC and CPPCC reveals the unspectacular side of Chinese celebrity politics by highlighting the links between celebrity and mundane aspects of governance.

\section{Categorizing celebrity politics}

David Marsh, Paul 't Hart, and Karen Tindall distinguish five main categories of people who embody the growing links between celebrity and politics in Western liberal-democratic societies. ${ }^{11}$ These are:

- politician celebrities - established politicians whose public behaviour, private life, or association with celebrities, alters their own public persona beyond the traditional political sphere into the celebrity sphere, either by intent or through accident/scandal

- politicians who use others' celebrity - political office holders who use the fame of entertainment and sports stars to endorse their candidature, party or policies

- celebrity politicians - high-visibility figures from traditionally non-political spheres (entertainment, arts and sports, and so on) who obtain legislative or executive office

- celebrity endorsers - high visibility figures from traditionally non-political spheres who offer financial and/or public support for a specific political candidate and/or party

- celebrity advocates - high visibility figures from traditionally non-political spheres who engage in political agenda-setting or policy-seeking behaviour, for example, by working on a relatively long-term basis for a particular cause with the goal of achieving policy change.

There are abundant examples of these five categories of people in the United States. President Bill Clinton offers a classic example of a politician celebrity, a man whose personal life and sexual behaviours became as much an object of scrutiny as his political decisions. President Barack Obama is a politician who uses others' celebrity to endorse his candidature, with more than 180 public figures, 
including musicians Bruce Springsteen and Jay Z, supporting the Obama campaign for presidential reelection in 2012. ${ }^{12}$ Well-known examples of celebrity politicians include actors Ronald Reagan (US President 1981-9) and Arnold Schwarzenegger (Governor of California 2003-11). Media mogul Oprah Winfrey provides an example of a celebrity endorser through her support of Barack Obama prior to the 2008 US Democratic Presidential Primary. ${ }^{13}$ The actress Angelina Jolie offers a prominent example of a celebrity advocate through her ambassadorial work since 2001 for the Office of the United Nations High Commissioner for Refugees. ${ }^{14}$

However, the categories developed by Marsh, 't Hart, and Tindall have reduced explanatory capacity in mainland China because of the system of one-party rule. There are no straightforward examples in the PRC of 'politicians who use others' celebrity' or 'celebrity endorsers' because major political leaders receive ample media coverage in state-controlled media outlets, and are not obliged to compete for media coverage and votes through party election campaigns. There are also no examples to date of celebrities, as opposed to local notables with money and/or positions of power and authority, endorsing candidates for rural village elections. ${ }^{15}$ This leaves only three categories to consider: (1) politician celebrities; (2) celebrity politicians; and (3) celebrity advocates.

\section{China's politician celebrities}

All of China's senior politicians are celebrities in the sense that they are household names, but they do not usually attract attention for their personal style and policy positions. Most prefer to adhere to the 'party line' and relatively little is usually known about their personal lives, other than forms of information that are considered permissible according to government controls. Thus, the majority of China's politicians would be more accurately described as public figures rather than as politician celebrities. A public figure typically becomes a celebrity when 'media interest in their activities is transferred from reporting on their public role (such as their specific achievement in politics or sport) to investigating the details of their personality and private lives'. ${ }^{16}$ This emphasis on the personal and private life distinguishes the contemporary celebritization of politicians from socialist hagiographic cults of personality that reified state leaders as the personification of Bolshevist-Maoist-Marxist ideologies and associated state power. Such cults also used the mass media to market political leadership, but in the context of closed societies that made media-transmitted criticism of a political leader or promotion of a political rival almost impossible.

In recent years, some senior CCP officials have become 'politician celebrities', for example, Wen Jiabao (PRC Premier 2002-12), Bo Xilai (former CCP Secretary in Chongqing Municipality) and President Xi Jinping. Wen was feted in the media as an 'approachable leader', receiving widespread publicity for meeting disaster-affected people, eating meals with people living in poor rural communities, encouraging public criticisms of government malfeasance, and using online forums to communicate with ordinary citizens before NPC meetings. ${ }^{17}$ Wen even responded to 
allegations of personal corruption from the New York Times by publicly asking the Politburo Standing Committee to launch an internal inquiry into his financial affairs. ${ }^{18}$ This populist style garnered him support as a political reformist, and criticism as the 'lead actor' in a party-led public relations campaign designed to distract people from the need for systemic change. ${ }^{19}$ Regardless of whichever characterization is more accurate, Wen's use of state-run broadcast and social media to communicate a personalized leadership style makes him a new type of reform-era politician celebrity.

Described as one of China's new wave of 'celebrity officials', Bo Xilai is a politician celebrity whose public behaviour, private life, and alleged association with celebrities has altered his public persona beyond the traditional political sphere. ${ }^{20}$ The son of a renowned political and military leader, Bo Xilai occupied a series of senior political posts until October 2012, when he was expelled from the $\mathrm{CCP}$ and removed from all state positions pending trial for corruption and disciplinary violations. ${ }^{21}$ Prior to his arrest, Bo Xilai cultivated a casual and charismatic image in the media that contrasted sharply with the usually staid media personas of senior Chinese officials. He also branded his leadership as being about 'people-centred economics' through the urban development policies adopted in Dalian City and Chongqing Municipality. Bo's prominent activities included: halting a Chongqing taxi-driver strike by meeting with drivers to hear their complaints over rising costs of living; promoting the mass singing of Mao-era songs and other 'feel good' events in work and public spaces; and using a policing and anti-corruption campaign to promote citizens' perceptions of safety and good governance, while simultaneously ousting his political rivals. ${ }^{22}$

In late 2013, Bo Xilai was sentenced to life imprisonment following a highly publicized trial for embezzlement and graft. ${ }^{23}$ His trial was conducted amid scandal that he had tried to cover up his wife's murder of a British entrepreneur and had used public funds to pay hundreds of women for sexual favours, including, allegedly, actress Zhang Ziyi. ${ }^{24}$ The extraordinary nature of the Bo Xilai case, and its entanglement with elite politics, corruption, sex and murder, led many commentators to declare that it was just like a Hollywood movie. ${ }^{25}$

Both examples demonstrate that senior officials in China are branding and celebritizing themselves and particular policies through personalized media appearances and the use of social media. The prominence of such strategies is underscored by the government-endorsed release of a Twitter-like SinaWeibo feed to provide near-verbatim records of parts of Bo Xilai's trial, even though journalists were prevented from attending. ${ }^{26}$ This highlights an increasingly sophisticated use of marketing communication strategies on the part of the ruling CCP.

Indeed, the English-language press has dubbed President Xi Jinping 'China's first social media president', claiming that his use of social media to publicize visits to rural villages and the nationwide anti-corruption drive may be defusing popular discontent and giving the CCP and its leader the public support required to maintain political power. ${ }^{27}$ Journalists have also noted the colourful, multidimensional personality associated with Chinese media presentations of Xi Jinping as a 'hard', 'corruption-fighting politician', the creator of the populist 'Chinese dream', and the 'soft' 
doting father and loving husband of a famous wife, which has prompted 'love songs about $\mathrm{Xi}$, odes to $\mathrm{Xi}$, academic papers about $\mathrm{Xi}$, cartoons of $\mathrm{Xi}$ and even action figures of $\mathrm{Xi} \cdot{ }^{28}$ Celebritized political communication therefore may help to market authoritarian rule by encouraging public empathy with political leaders, a practice that is sometimes characterized more cynically in Western contexts as 'the politics of distraction'. 29

\section{Celebrities and the NPC: China's celebrity politicians?}

While there are no celebrity politicians in contemporary China of the ilk of Reagan and Schwarzenegger, there are numerous examples of Chinese celebrity politicians if membership of the NPC is counted as an example of holding political office. The NPC is nominally the supreme organ of state power in China; its main functions and powers include formulating laws and policy, delegating authority and supervising other governing organs. However, the major content of those laws and policies are usually determined in advance by government departments and party committees, earning it the moniker of a rubber stamp legislature or 'empty political theatre'. ${ }^{30}$ The full NPC congress of nearly 3000 delegates has a functioning term of five years, but 'meets only once per year in March for a period of two or three weeks'. ${ }^{31}$ Delegates are also nominated for election by party and government organizations based on 'hard quotas and selection norms' that are linked to geography, ethnicity, gender and party affiliation, ${ }^{32}$ and continue their normal fulltime employment during their term of office. The primary benefit of NPC (and CPPCC) membership is generally seen to be confirmation of high social standing, a 'reputation boost' fostering an individual's professional and business development, and a rare opportunity to participate to some extent in public policy development. ${ }^{33}$

The list of delegates to the 11th NPC (2008-12), which was issued by the People's Daily (人 民日报) on 29 February 2008, contained 2987 names. ${ }^{34}$ Although the NPC website contains information about delegates' age, gender, education and party membership, it does not always provide details about their careers. ${ }^{35}$ A search was therefore conducted on the popular Chinese search engine Baidu, in March-April 2014, for the occupation of delegates in cases where such information was not provided on the NPC website. This process revealed that at least 30 people (1\%) of the total number of delegates were celebrities in the fields of commercial entertainment, arts or sports, which is significantly lower than that for corporate CEOs, around 500 people (17\%) of the total number of delegates. ${ }^{36}$ Hence, to the extent that these forums can be described as 'new rich clubs', they are populated by business figures rather than entertainment and sports celebrities. ${ }^{37}$

Most of these celebrity delegates attracted media publicity for presenting or supporting motions to the NPC about policy development. Data about such motions were collected from searches on Baidu because the NPC website does not provide records of motions at the 11th NPC while records of motions presented at the 10th NPC are incomplete. Delegates or relevant departments can submit 
motions to the NPC with the support of the presidium of the NPC, the Standing Committee of the NPC, the State Council, the Supreme People's Court, the Supreme People's Procuratorate, a provincial-level delegation of representatives to the NPC, or a group of at least 30 NPC delegates. ${ }^{38}$ The NPC presidium decides if a motion is to be included in the agenda of an NPC session, or whether it should be first given to a sub-committee for further examination. Motions that are included on the agenda are discussed by delegates and referred to a sub-committee for examination. Subject to approval, they are then submitted by the presidium to a plenary session of the NPC for a vote. Motions that obtain a majority vote are accepted and become legally binding.

Delegates are expected to contribute to policy formulation at the NPC despite its rubber stamp moniker, as demonstrated by media criticisms in 2012 of Yang Wei, an Olympic gymnast. He was criticized for failing to submit any motions during his term of office. Although Yang attributed this failure to inexperience, critics argued that he was more interested in promoting his career than fulfilling his political duties because even high-school students have submitted motions to the NPC. ${ }^{39}$ Critics concluded that celebrities are inappropriate political representatives, given the limited spaces available for citizen participation in formal Chinese politics. ${ }^{40}$

Yang Wei's case is unusual; most celebrity delegates at the 11th NPC attracted media publicity for presenting motions relating to their general area of professional expertise (sports/health, arts/culture), or supporting calls of the PRC government to expand community-based volunteering and assist disadvantaged people. ${ }^{41}$ Yang Yang, an Olympic speed skating champion, proposed that the Ministry of Education should make school principals responsible for improving the health of youth by making students engage in one hour of physical education daily. ${ }^{42}$ Lei Ayouduo, a Miao folk singer, and Dilina'er Abudula, a Uyghur folk dancer, proposed expanding ethnic minority cultural tourism and the culture industries respectively. ${ }^{43}$ Tan Jing, a solo singer in the Song and Dance Ensemble of the People's Liberation Army, proposed every year between 2008-12 that state-owned enterprises should subsidize volunteering by giving workers paid time off from work to provide services for the children of rural-to-urban migrant workers. ${ }^{44}$

However, none of the motions put forward by celebrity delegates at the 11th NPC resulted in policy change. Tan Jing's motion on volunteerism appears to be the only 'celebrity-endorsed' motion that was considered by the NPC, and that was in the context of broader discussions about the need to expand legislation on volunteering. ${ }^{45}$

The term celebrity politician is thus perhaps too strong for the largely symbolic role performed by celebrity delegates at the NPC. Likewise, the term 'celebrity endorser' inaccurately suggests that they are broadening the parameters of political debate by endorsing certain politicians and policies in preference to others. It appears that the role of celebrities in the NPC is to endorse existing government policies or advocate for policy amendments that will complement government policies, rather than introducing alternative policies and acting as an organized form of political 
opposition or potential check on executive power. As a result, China's celebrity politicians might be more appropriately termed 'celebrity Party-supporters'.

However, the case of Ding Liguo, an entrepreneur and delegate for Hebei Province at the 11th NPC, demonstrates that elite advocacy can contribute to policy change. Ranked number 140 on the Forbes list of China's 400 richest people in 2008, Ding is the Chair of Delong Holdings, a private steel manufacturing and trading company. ${ }^{46}$ Ding submitted a motion to the NPC in March 2012 on banning shark-fin soup at state-funded banquets. ${ }^{47}$ International conservation groups contend that the demand for shark fin, an established component of Chinese haute cuisine, is endangering open-ocean shark populations. ${ }^{48}$ A reply from the administrative office of the State Council dated 16 June 2012 stated that legislation would result by $2015 .{ }^{49}$ On 8 December 2013, the Central Committee of the $\mathrm{CCP}$ and the State Council issued the Regulations on Domestic Official Hospitality for Party and Government Organs. Article 9 states: 'Official dinners should not involve: high-end cuisine or dishes that contain shark fin, bird's nest, or any protected animal; cigarettes and premium drinks; the use of private clubs; and high consumption costs. ${ }^{50}$

Ding's motion flowed from his involvement in shark protection activities coordinated by the China Entrepreneur Club (CEC) - a non-profit elite club founded in 2006 to promote entrepreneurial exchange and sustainable development - of which Ding is a member, and WildAid, an international non-governmental organization (NGO) committed to wildlife conservation. ${ }^{51}$ WildAid has distributed a series of celebrity-endorsed public service announcements in China about the need for shark protection. Two of these feature Yao Ming, former professional basketball player and member of the Shanghai CPPCC; another features five members of the CEC: Huang Nubo (Zhongkun Investment Group); Feng Lun (Vantone Real Estate); Li Dongsheng (TCL Corporation); Hu Baosen (Jianye Real Estate); and Wei Xue (China Public Relations and Consultants). ${ }^{52}$ Apart from leveraging Ding's political position and appearing in WildAid's public service announcements, members of the CEC have engaged in numerous publicized shark protection activities. For example, the CEC was involved in the roll-out of shark protection initiatives in different Chinese cities between 2011-13, using the slogans 'No shark-fin soup for New Year banquets' and 'Create zero-shark-fin cities: Don't eat in shark-fin restaurants'. ${ }^{3}$

The introduction of a ban on shark fin at official banquets highlights the potential for environmental NGOs and elite activists to influence domestic governance in China, even though that ban cannot be directly attributed to their activities. In December 2012, the incoming Party Secretary and PRC President, Xi Jinping, introduced eight measures to improve the work habits of government employees and reduce corruption, including curbing extravagant spending. ${ }^{54}$ The State Council presumably agreed to consider Ding's motion because the central government had already committed to the now popular austerity measures.

However, the fact that domestic non-profit organizations working with international NGOs were able to roll out shark protection activities across multiple media and sociopolitical spaces 
suggests that the involvement of celebrities and corporate figures in the NPC could be a positive force for social change in China, given the limited spaces available for broader political participation. The next sections develop this contention by examining celebrity advocacy in the context of the political space provided by the CPPCC.

\section{Celebrities and the CPPCC: Party-policy supporters?}

There are even more examples of celebrity politicians in China if membership of the CPPCC is counted as an example of holding political office. The CPPCC has a national committee and local committees with functioning terms of five years, and the National Committee meets in Beijing at the same time as the NPC. The CPPCC is comprised of selected representatives from CCP-endorsed people's organizations and the eight permitted non-communist parties that support the CCP, and includes professionals, entrepreneurs, intellectuals, returned overseas Chinese, representatives of Chinese ethnic minorities, and people from Hong Kong, Macao and Taiwan. The main task of CPPCC representatives is to provide political consultation about the handling of state affairs, typically by validating major principles and policies proposed by the central and local governments on political, economic, cultural and social affairs.

Members of the CPPCC National Committee can contribute to policy formation by submitting proposals. Unlike NPC motions, there are no restrictions on the timing, scope and number of sponsoring members for the presentation of a proposal. However, proposals accepted by the CPPCC are not legally binding. ${ }^{55}$

The 11th National Committee of the CPPCC (2008-12) was originally comprised of 2237 delegates, ${ }^{56}$ with an Internet search for the occupation of those delegates revealing that at least 139 delegates (6\% of the total number of delegates) were entertainment, arts or sports stars. An additional search for proposals on the official website of the National Committee of the CPPCC, ${ }^{57}$ and on Baidu using the name of each celebrity and the term 提案 (submitting proposal), revealed that most celebrity delegates had presented proposals, either as individuals or as part of a group (113 people). In fact, more than half of the celebrity delegates had put their name to more than one proposal ( 83 people). Only 26 celebrity delegates could not be clearly associated with a proposal.

Although celebrity delegates at the 11th CPPCC put forward over 200 proposals, only six of these proposals can be verified as having been accepted and resulting in policy change. This figure is not necessarily exact because there is no information released at the national level on the nature and results of different proposals. The CPPCC website does not list every proposal that is presented at the annual meetings, and related media reports do not always indicate whether a particular proposal was successful or not. However, it appears that celebrity delegates generally have a limited impact on policy formation at the CPPCC. 
The issues raised by the six successful proposals highlight the intertwining of celebrity with mundane rather than glamorous aspects of Chinese governance. Ye Qiaobo, an Olympic speed skater, was part of a proposal in 2011 on reducing traffic accidents by encouraging civil driving practices. ${ }^{58}$ Wang Mingming (artist) and Ouyang Zhongshi (calligrapher) were involved in a proposal in 2010 to improve youth education relating to the writing of Chinese characters. ${ }^{59}$ Wan Shanhong (soprano) was part of a proposal in 2008 suggesting that the national anthem should be sung at meetings of the NPC and CPPCC, rather than members listening to a recording. ${ }^{60}$

The other successful proposals focused on improving the quality of life of the orphaned and disabled as mandated by the PRC's 10th and 11th Five-Year Plans for National Economic and Social Development. ${ }^{61}$ Han Hong, a singer, was involved in a proposal in 2009 to increase the living allowance of orphans. ${ }^{62}$ Tai Lihua, a dancer who is hard of hearing, was involved in two successful proposals put forward in 2008: one on improving the ability of disabled persons to obtain driving licences; and the other on making checks for disabilities a compulsory part of general health checks for children between 0 and 6 years (this service is provided in Tianjin). ${ }^{63}$

Unsuccessful proposals similarly advocated expanding government services in areas of established public concern. In 2007-8, Peng Liyuan, wife of President Xi Jinping, who is also a soprano, the national ambassador for Tuberculosis Control and Prevention, as well as Goodwill Ambassador with the World Health Organization for Tuberculosis and HIV/AIDS, ${ }^{64}$ put her name to unsuccessful proposals on: establishing a mentoring network of youth career counsellors; improving services for children orphaned by AIDS, and developing Tuberculosis prevention legislation. ${ }^{65}$ Yang Lan, a media producer and TV talk-show host, supported numerous unsuccessful proposals between 2009 and 2012, including: encouraging college student's involvement in community work; providing vocational education for the children of rural-to-urban migrant workers; and introducing a national charity law. ${ }^{66}$ Han Hong, mentioned earlier, supported unsuccessful proposals between 2008-12 on: strengthening patriotic education for youth; enhancing the safety from sexual predation of girls left behind in rural areas by parents working in cities; rescuing street children; and developing a child welfare law. ${ }^{67}$

Ten unsuccessful proposals attracted the support of four or more celebrities, indicating either shared interests or perhaps the fact that they were placed on the same subcommittee. Delegates at the National Committee of the CPPCC routinely discuss policy in small groups of around 30 people. These groups and the topics they discuss are often not aligned with an individual's area of professional expertise, ${ }^{68}$ which may limit the potential for 'expert opposition' while arguably also allowing delegates to debate a broad range of issues.

The issues raised by these 10 proposals underscore the links between Chinese celebrity politics and mundane government, with two on the film industry perhaps highlighting areas of selfinterest. Listed in descending order based on the number of celebrity supporters, the proposals were on: (1) standardizing domestic housekeeping services (16 celebrities); ${ }^{69}$ (2) banning shark-fin soup at 
official banquets ( 16 celebrities $) ;{ }^{70}$ (3) monitoring cultural products targeting youth (14 celebrities) $;^{71}$

(4) using child education to promote traditional culture and improve the quality of Chinese nationals (13 celebrities) $;{ }^{72}$ (5) banning the trade in shark fin ( 9 celebrities) $;{ }^{73}$ (6) establishing a Chinese calligraphy museum (9 celebrities) $;^{74}(7)$ strengthening the use and management of scientific research achievements ( 5 celebrities) $;{ }^{75}$ (8) supporting the film industry ( 5 celebrities) $;^{76}$ (9) establishing cinemas in small and medium-sized cities ( 5 celebrities) $;{ }^{77}$ and (10) teaching traditional Chinese characters in primary schools ( 4 celebrities) ${ }^{78}$

The proposal on banning shark-fin soup at official banquets highlights the involvement of China's celebrity party supporters in new elite networks that are connected in part through philanthropy, a developing field of social action in China. This proposal was not accepted at the CPPCC. However, the same motion resulted in policy change when presented at the NPC, as already discussed. Wan Jie, Chair of the Shenzhen Artron Color Printing Company, proposed banning the trade in shark fin at the 2011 meeting of the CPPCC and banning shark-fin soup at official banquets in 2012. Wan Jie is the vice-president of the Alxa SEE Ecological Association (2004-14), a non-profit environmental protection organization founded in 2004 by 100 entrepreneurs, some of whom are also members of the CEC. Wan Jie's shark protection proposals reportedly obtained the support of 45 delegates in 2011, including celebrities such as Yang Lan. ${ }^{79}$ The links between shark protection activities at the NPC and CPPCC provide one example of new elite networks operating to shape sociopolitical participation as members of formal government institutions and non-profit organizations.

Unsurprisingly, given China's system of one-party rule, this example suggests that the use of celebrity within the political space of the CPPCC is chiefly about communicating support for Party policies or introducing uncontroversial policy developments. In other words, to the extent that celebrities in the CPPCC are celebrity politicians they are celebrity Party-policy supporters. However celebrities can adopt political advocacy roles, as demonstrated by the example of Li Yinhe.

\section{Celebrity advocacy}

Li Yinhe, an academic, offers an example of a celebrity advocate; she is a high visibility figure from a traditionally non-political sphere who has used the political space provided by the annual meetings of the NPC and CPPCC to advocate for over a decade for the legalization of same-sex marriage in China. Li joined the Beijing-based Chinese Academy of Social Sciences in 1992, a prestigious governmentaffiliated think tank. She was previously at the Academy's Institute of Marxism-Leninism and Mao Zedong Thought, but subsequently worked as a professor of sociology - a discipline that was disregarded in the PRC until the early 1980s as non-Marxist, and thus having limited explanatory capacity. Now retired, $\mathrm{Li}$ is a renowned advocate of sexual rights. 
$\mathrm{Li}$ is such a sought-after media spokesperson on sex-related matters that she claims to have started charging fees for interviews to stop journalists from wasting her time by failing to first research her opinions, which are publicly available through her publications and blogs ${ }^{80}$ In November 2005, Li started a blog on Sina.com, one of China's most popular Internet portals. By November 2015, her blog had over 3800 postings and had received over 94 million visitors. ${ }^{81}$

$\mathrm{Li}$ is not a CPPCC delegate, although she is often cited as such; however, she lobbied CPPCC delegates to present proposals on her behalf on legalizing same-sex marriage to the national meetings of the CPPCC in 2003, 2005, 2006, 2008 and 2012. All of these attempts failed to get the subject of same-sex marriage on the policy agenda. The proposal only obtained sufficient support from delegates to be discussed at the CPPCC in 2005, when it was rejected as lacking sufficient detail for sustained discussion. ${ }^{82}$

In 2012, Li attempted but failed to have her proposal on same-sex marriage presented to the NPC by Chi Susheng, a lawyer and NPC delegate from Heilongjiang Province with an equally controversial history of advocating for the legalization of sex work in China. ${ }^{83}$ In 2006, Chi called on NPC delegates to legalize the sex industry and control the spread of HIV, by restricting commercial sexual activities to licensed venues and requiring sex workers to have regular health checks with official certification. ${ }^{84}$ Her motion received the signed support of 33 NPC delegates, but was vetoed from discussion on technical grounds. In media interviews, Chi claimed that senior leaders had vetoed the motion because of its controversial content. ${ }^{85}$

Li's efforts to bring the issue of same-sex marriage to the attention of the CPPCC and NPC have attracted widespread publicity, even though they failed to obtain formal political support. She has been praised for promoting sexual diversity and human rights, and criticized for encouraging 'abnormal' behaviours. ${ }^{86} \mathrm{Li}$ has also claimed in an interview that she will continue to advocate for same-sex marriage, even if achieving that goal demands another 20 years of activism on her part. ${ }^{87}$

Li's advocacy highlights an emerging space for civic action that is both within and outside of Party-state structures. Li's celebrity is a function, rather than precondition, of her advocacy; she has achieved celebrity status because of her long-term advocacy on sex-related issues. However, the example of Li Yinhe demonstrates that celebrity advocacy targeting the annual meetings of the NPC and CPPCC can sometimes open the space for discussion of alternative policies and politics.

\section{Concluding remarks}

Celebrity politics is a growing phenomenon in many countries around the world, including the PRC. While typologies of celebrity politics in Western countries have the broadest application to modern liberal democracies, the emergence of new elites and media forms means they have resonance even in authoritarian, non-democratic polities such as China. In recent years, some of China's political figures have adopted the media tools of celebrity to brand themselves and particular policies through 
personalized media appearances and the use of social media. This highlights an increasingly

sophisticated use of marketing communication strategies on the part of the CCP.

The examples of celebrity delegates within the political spaces of the NPC and CPPCC shed light on the links between celebrity and elite politics, revealing a broadening of elite networks that usually supports but occasionally also challenges government policies. Notwithstanding these limitations, the examples of Ding Liguo (the 'front man' for elite activism on shark protection) and $\mathrm{Li}$ Yinhe (an individual advocate for same-sex marriage) demonstrate that these political spaces can in some instances be used to generate new policies and to promote public discussion of alternative politics. An examination of the motions and proposals presented by celebrity delegates to these bodies demonstrates the mundane nature of their political involvement. The 'ordinariness' of their publicized concerns differs from the proclaimed spectacularism of Western celebrity politics ${ }^{88}$ and perhaps suggests a desire on the part of China's elites to be seen to be acting in the interests of 'the Chinese people'. At the same time, the failure of these celebrities to gain traction for policy changes unless they align with prevailing Party priorities indicates that media coverage of their political involvement has not accorded them the social authority that makes celebrity politics such a controversial feature of Western liberal democracies.

\section{Notes}

This research was supported under the Australian Research Council's Future Fellowship funding scheme (FT100100238).

${ }^{1}$ Andrew F. Cooper, Celebrity Diplomacy, Boulder, CO: Paradigm Publishers, 2008; Ilan Kapoor, Celebrity Humanitarianism: The Ideology of Global Charity, London and New York: Routledge, 2013; and Liza Tsaliki, Christos A. Frangonikolopoulos, and Asteris Huliaras (eds), Transnational Celebrity Activism in Global Politics: Changing the World?, Bristol and Chicago: Intellect Press, 2011.

${ }^{2}$ David Marsh, Paul 't Hart, and Karen Tindall, Celebrity politics: The politics of the late modernity?, Political Studies Review 8(3), 2010: 322-40.

${ }^{3}$ Kapoor, Celebrity Humanitarianism; Timothy C. Weiskel, From sidekick to sideshow - Celebrity, entertainment, and the politics of distraction: Why Americans are 'sleepwalking towards the end of the earth', American Behavioral Scientists 49(3), 2005: 393-409; and Liesbet van Zoonen, The personal, the political and the popular: A woman's guide to celebrity politics, European Journal of Cultural Studies 9(3), 2006: $287-301$. ${ }^{4}$ Tyler Cowen, What Price Fame?, Cambridge, MA: Harvard University Press, 2000; Darrell M. West and John Orman, Celebrity Politics: Real Politics in America, Upper Saddle River, NJ: Prentice Hall, 2003.

${ }^{5}$ Marsh, 't Hart, and Tindall, Celebrity politics.

${ }^{6}$ Louise Edwards and Elaine Jeffreys, Celebrity in China, Hong Kong: Hong Kong University Press, 2010; David S. G. Goodman, Class in Contemporary China, Cambridge: Polity Press, 2014.

${ }^{7}$ The CPPCC was first convened in Chongqing in 1946 by the Nationalist Party of China. The second meeting was convened under the rubric of a 'new political consultative conference' in September 1949 to assist with the 
election of members of the State Council and to decide on the capital city, the national flag, the national anthem and the calendar, of the People's Republic of China. See Minglu Chen, From economic elites to political elites: Private entrepreneurs in the People's Political Consultative Conference, Journal of Contemporary China 24(94), 2015: 615-16.

${ }^{8}$ Rory Truex, The returns to office in a 'rubber stamp' parliament, American Political Science Review 108(2), 2014: 235-51.

${ }^{9}$ Michael Evans, Yao Ming is China's newest popular, controversial celebrity politician, Asian Correspondent, 28 January 2012, http://asiancorrespondent.com/74757/yao-ming-is-chinas-newest-popular-controversialcelebrity-politician/, accessed 26 October 2015.

${ }^{10}$ Minglu Chen, From economic elites to political elites; Chen Zhao, Lu Ming, and He Junzhi, Power and political participation of entrepreneurs: Evidence from Liuzhou, Guangxi, China, Journal of the Asia Pacific Economy 13(3), 2008: 298-312; Goodman, Class in Contemporary China; and Truex, The returns to office in a 'rubber stamp' parliament.

${ }^{11}$ Marsh, 't Hart, and Tindall, Celebrity politics.

${ }^{12}$ As it happened: Barack Obama defeats Mitt Romney to win second term as US president, News.com.au, 7 November 2012, http://www.news.com.au/world/live-barack-obama-mitt-romney-in-final-stretch-of-election2012/story-fndir2ev-1226511582131, accessed 9 November 2015; Douglas Kellner, Celebrity diplomacy, spectacle and Barack Obama, Celebrity Studies 1(1), 2010: 121-3.

${ }^{13}$ Craig Garthwaite and Tim Moore, The role of celebrity endorsements in politics: Oprah, Obama, and the 2008 Democratic Primary, August 2008,

http://www.stat.columbia.edu/ gelman/stuff_for_blog/celebrityendorsements_garthwaitemoore.pdf, accessed 4 March 2015.

${ }^{14}$ Angelina Jolie Pitt: a special envoy for refugee issues, UNHCR,

http://www.unhcr.org/pages/49c3646c56.html, accessed 9 November 2015.

${ }^{15} \mathrm{Xu}$ Yiqing, Cunzhuang xuanju gei Zhongguo nongcun dai laile shenme? Wenxian zongshu ji yixie xin de zhengju (What do Chinese village elections bring? A literature review and some new evidence), Beijing daxue Zhongguo jingji yanjiu zhongxin (China Center for Economic Research, Peking University), n.d., 9-10, http://www.mit.edu/ xyq/papers/chinese/Xu_electionreview.pdf, accessed 13 November 2015.

${ }^{16}$ Graeme Turner, Understanding Celebrity, London: Sage, 2004, 8.

${ }^{17}$ David Barboza, China leader encourages criticism of government, The New York Times, 26 January 2011, A9; Fareed Zakaria, Interview with Wen Jiabao, $C N N, 3$ October 2010,

http://edition.cnn.com/TRANSCRIPTS/1010/03/fzgps.01.html, accessed 9 November 2015; J. R. Wu and Jason Dean, Wen engages web users in rare chat: Chinese Premier, reflecting government's growing Internet use, addresses economy, U.S. ties, but avoids politics, The Wall Street Journal, 1 March 2010, http://www.wsj.com/articles/SB10001424052748704089904575093102225297546, accessed 9 November 2015. ${ }^{18}$ China communist party to probe Wen family wealth: SCMP, Reuters, 4 November 2012, http://www.reuters.com/article/2012/11/05/us-china-wen-wealthidUSBRE8A402I20121105\#aJIS3ulTCvv6Fulg.99, accessed 9 November 2015. 
${ }^{19}$ Rachel Lu, Weibo reaction to Wen Jiabao's corruption, Foreign Policy, 26 October 2012, http://foreignpolicy.com/2012/10/26/weibo-reaction-to-wen-jiabaos-corruption/), accessed 10 November 2015; Yu Jie, Zhongguo yingdi Wen Jiabao (China's Best Actor: Wen Jiabao), Hong Kong: New Century Press, 2010.

${ }^{20}$ Jiang Yekui, Zhongguo mingxing guanyuan de shidai tezheng (The distinctive features of contemporary Chinese celebrity officials), 15 July 2005, http://finance.sina.com.cn/review/20050715/10391800522.shtml, accessed 1 June 2015.

${ }^{21}$ Bo Xilai [biography], http://chinavitae.com/biography/Bo_Xilai/full, accessed 4 March 2015.

${ }^{22}$ Carolyn Cartier and Luigi Tomba, Symbolic cities and the 'cake debate', in Geremie R. Barmé (ed.) China Story Yearbook 2012: Red Rising, Red Eclipse, Canberra: Australian Centre on China in the World, 2012, 26-52; Going down fighting: China has been gripped by an extraordinary courtroom drama, The Economist, 31 August 2013, http://www.economist.com/news/china/21584367-china-has-been-gripped-extraordinary-courtroomdrama-going-down-fighting, accessed 2 June 2015.

${ }^{23}$ John Sudworth, Chinese court rejects Bo Xilai appeal and upholds life sentence, BBC News China, 25 October 2013, http://www.bbc.com/news/world-asia-china-24652525, accessed 10 November 2015.

${ }^{24}$ Malcolm Moore and Philip Sherwell, Crouching Tiger star fights claims she was one of Bo's '100 mistresses', The Age, 30 September 2012, http://www.theage.com.au/world/crouching-tiger-star-fights-claims-she-was-oneof-bos-100-mistresses-20120930-26t49.html?skin=text-only, accessed 10 November 2015.

${ }^{25}$ Zheng Wang, The Bo Xilai verdict: Everybody wins, The Diplomat, 22 September 2013, http://thediplomat.com/2013/09/the-bo-xilai-verdict-everybody-wins/, accessed 10 November 2015. ${ }^{26}$ Going down fighting.

${ }^{27}$ David Cohen, Xi Jinping: China's first social media president?, The Diplomat, 8 January 2013, http://thediplomat.com/2013/01/xi-jinping-chinas-first-social-media-president/, accessed 9 November 2015. ${ }^{28}$ Tom Phillips, Xi Jinping: The growing cult of China's 'Big Daddy Xi', The Telegraph, 8 December 2014, http://www.telegraph.co.uk/news/worldnews/asia/china/11279204/Xi-Jinping-the-growing-cult-of-Chinas-BigDaddy-Xi.html, accessed 10 November 2015.

${ }^{29}$ Weiskel, From sidekick to sideshow.

${ }^{30}$ The National People's Congress: What makes a rubber stamp?, The Economist, 5 March 2012, http://www.economist.com/blogs/analects/2012/03/national-peoples-congress, accessed 10 November 2015; Truex, The returns to office in a 'rubber stamp' parliament, 237.

${ }^{31}$ Truex, The returns to office in a 'rubber stamp' parliament, 237.

${ }^{32}$ Ibid, 237.

${ }^{33}$ Minglu Chen, From economic elites to political elites, 624-6; Chen, Lu, and He, Power and political participation of entrepreneurs; Goodman, Class in Contemporary China, 90-1; and Truex, The returns to office in a 'rubber stamp' parliament, 236.

${ }^{34}$ Zhonghua Renmin Gongheguo di shiyi jie Quanguo Renmin Daibiao Dahui daibiao mingdan (List of delegates at the 11th National People's Congress of the People's Republic of China), Renmin ribao (People's daily), 29 February 2008, 2.

${ }^{35}$ Daibiao mingdan (List of delegates), Quanguo Renmin Daibiao Dahui (The National People's Congress of the People's Republic of China), http://www.npc.gov.cn/delegate/delegateArea.action, accessed 1 June 2015. 
${ }^{36}$ Truex, The returns to office in a 'rubber stamp' parliament, 236.

${ }^{37}$ Minglu Chen, From economic elites to political elites, 623.

${ }^{38}$ Backgrounder: NPC motions and CPPCC proposals, China Daily, 2 February 2015, http://www.chinadaily.com.cn/china/2015twosession/2015-03/02/content_19696372.htm, accessed 9 November 2015

${ }^{39} \mathrm{Yu}$ Wenjun, Daibiao weiyuan xu yongxin lü zhi (NPC delegates should fulfil their duties), Xibu shangbao (Western daily), 5 March 2012, http://www.xbsb.com.cn/xbsbnews/hhpl/hhpl/2012-03-05/208521.html, accessed 10 November 2015.

${ }^{40}$ Ibid.

${ }^{41}$ Shouquan fabu: Zhonghua Renmin Gongheguo guomin jingji he shehui fazhan di shiyi ge wunian guihua gangyao (quanwen) (Authorized release: PRC's 11th Five-Year Plan for national economic and social development (full text)), 2006, http://news.xinhuanet.com/misc/2006-03/16/content_4309517.htm, accessed 4 March 2015.

${ }^{42}$ Zhao Renwei and Gao Peng, Quanguo Renda daibiao Yang Yang: Zhongxiaoxuesheng meitian duanlian yi xiaoshi bu luoshi ying wenze xiaozhang (NPC delegate Yang Yang: Principals should be made accountable for not implementing the daily one-hour physical exercise for primary and secondary school students), Xinhua, 8 March 2012, http://www.bj.xinhuanet.com/bjpd-zhuanti/2012-03/08/content_24853643.htm, accessed 2 June 2015.

${ }^{43}$ Duan Zelin, Dilina'er Abudula daibiao: Jianyi tigao wenhua congye renyuan daiyu (Delegate Dilina'er Abudula: Recommends improving the treatment of professionals in the culture industry), Zhongguo yishubao (China art news), 11 March 2011, http://www.cflac.org.cn/zt/2011-03/11/content_22260295.htm, accessed 10 November 2015; Wu Wei and Luo Jing, Lei Ayouduo: Fazhan minzu wenhua lüyou chanye tigao xingfu gan (Lei Ayouduo: Develop the ethnic minority culture tourism industry and promote happiness), Tencent, 4 March 2011, http://news.qq.com/a/20110304/002342.htm, accessed 2 June 2015.

${ }^{44}$ Tan Jing yu wei Zhongguo zhiyuanzhe lifa: Yin kan dao tamen de weida ke'ai (Tan Jing calls for volunteer legislation: Because she saw how great and lovely they are), Zhongguo xinwenwang (China news net), 6 March 2012, http://www.chinanews.com/yl/2012/03-06/3721792.shtml, accessed 4 March 2015.

${ }^{45}$ Ibid.

${ }^{46}$ The 400 richest Chinese: \#140 Liguo Ding \& family, Forbes, 29 October 2008, http://www.forbes.com/lists/2008/74/chinarichest08_Liguo-Ding-family_9S0Y.html, accessed 17 March 2015. ${ }^{47}$ Yuan Jiansheng, 'Jinshi yuchi': Lifa de shangjie liliang ('Ban the eating of shark fin': The power of the business community to make legislation), 25 July 2012, http://www.daonong.com/g/17/tianxia/2012/0725/34647.html, accessed 2 June 2015.

${ }^{48}$ WildAid, Sharks, http://www.wildaid.org/sharks, accessed 4 March 2015.

${ }^{49}$ Yuan, 'Jinshi yuchi'.

${ }^{50}$ Zhonggong Zhongyang Bangongting, Guowuyuan Bangongting yinfa 'Dangzheng jiguan guonei gongwu jiedai guanli guiding' (The General Office of the Central Committee of the Chinese Communist Party and the State Council issue 'Regulations on Domestic Official Hospitality for Party and Government Organs'), 
Xinhuawang, 8 December 2013, http://news.xinhuanet.com/politics/2013-12/08/c_118467426.htm, accessed 2 June 2015.

${ }^{51}$ About us [China Entrepreneur Club], http://www.daonong.com/English/cec_about.html, accessed 9 November 2015; WildAid, Sharks.

${ }^{52}$ Shipin: Yesheng Jiuyuan gongyi guanggao (Video: WildAid public service announcement), Youku, http://v.youku.com/v_show/id_XNTIzNDU3NzQ4.html, accessed 4 March 2015; WildAid PSA - Yao Ming: Shark fin soup, Youtube, 15 December 2009, http://www.youtube.com/watch?v=mJG7RaLX-

DM\&feature=relmfu, accessed 4 March 2015; and WildAid PSA - Yao Ming: The price of shark fin soup, Youtube, 29 September 2011, http://www.youtube.com/watch?v=G7oaTCBuI2g, accessed 4 March 2015.

${ }^{53}$ Bai jia jigou zai Beijing lianhe changyi 'nianfan ling yuchi' (100 organizations launch a 'No shark-fin soup for New Year banquets' initiative in Beijing), Tencent, 23 December 2011, http://news.qq.com/a/20111223/000533.htm, accessed 2 June 2015; Yang Xiaohong, Shenzhen, Zhongguo shou ge 'ling yuchi chengshi' husheng zuigao? (Shenzhen: The loudest voice for the first 'zero shark-fin city' in China?), Nanfang dushibao (Southern metropolis daily), 26 July. http://gongyi.oeeee.com/ndgyzk/201206/t20120604_1310212.html, accessed 9 November 2015.

${ }^{54}$ Zhonggong Zhongyang Zhengzhiju zhaokai huiyi, shenyi guanyu gaijin gongzuo zuofeng, miqie lianxi qunzhong de youguan guiding - fenxi yanjiu 2013 nian jingji gongzuo: Zhonggong zhongyang zong shuji Xi Jinping zhuchi huiyi (The Politburo of the Central Committee of the Chinese Communist Party calls for a meeting to discuss relevant regulations on improving work style and public relations - analysis of economic work in 2013: General Secretary Xi Jinping presides over a meeting), Renmin ribao (People's daily), 5

December 2012, 1.

${ }^{55}$ Backgrounder.

${ }^{56}$ Zhongguo Renmin Zhengzhi Xieshang Huiyi di shiyi jie Quanguo weiyuanhui weiyuan mingdan (List of delegates at the 11th National Committee of the Chinese People's Political Consultative Conference), Renmin ribao (People's daily), 26 January 2008, 2.

${ }^{57}$ Ti'an ji ban fu xuandeng (Selected proposals and responses), Zhongguo Renmin Zhengzhi Xieshang Huiyi Quanguo weiyuanhui (The National Committee of the Chinese People's Political Consultative Conference), http://www.cppcc.gov.cn/zxww/zxww/tajbfxd/index.shtml, accessed 4 March 2015.

${ }^{58}$ Wang Yongsheng, Gong'anbu: Yi zhuoshou xiugai jiazhao guifan (Ministry of Public Security: Modifying regulations regarding drivers' licences), Fazhi wanbao (The mirror), 8 January 2012, A11.

${ }^{59}$ Zhang Yumei, Bie rang shufa jiaoyu 'liubianzou' (Don't let calligraphy education 'slide'), Guangming ribao (Guangming daily), 24 November 2010, 1.

${ }^{60}$ Zhou Xiaohua and Wang Jie, Wan Shanhong weiyuan jianyi: 'Chang guoge' daiti 'zou guoge' (Delegate Wan Shanhong's suggestion: Replace 'playing the national anthem on musical instruments' with 'singing the national anthem'), Changsha wanbao (Changsha evening news), 4 March 2008, http://www.changsha.cn/zt/ztguonei/2008h/16/200803/t20080304_801164.htm.

${ }^{61}$ Zhonghua Renmin Gongheguo guomin jingji he shehui fazhan di shi ge wunian jihua gangyao (PRC's 10th Five-Year Plan for national economic and social development), 2001, 
http://www.people.com.cn/GB/historic/0315/5920.html, accessed 13 November 2015; Shouquan fabu:

Zhonghua Renmin Gongheguo guomin jingji he shehui fazhan di shiyi ge wunian guihua gangyao, 2006.

${ }^{62}$ Han Hong: Wo you 200 duo ge gu'er, Zhongguo jiaoyu zhuangkuang yipian dahao (Han Hong: I support more than 200 orphans, China's education system is excellent), 4 March 2010,

http://news.163.com/10/0304/20/60V7CL1J000146BC.html, accessed 4 March 2015.

${ }^{63}$ Pan Wen, Yong guan'ai chengqi yipian qingkong (Hold up a clear sky with love), Renmin ribao (People's daily), 28 April 2010, 20.

${ }^{64}$ On Peng Liyuan, see Johanna Hood, Peng Liyuan's humanitarianism: morality, politics and eyeing the present and past, Celebrity Studies 6 (4), 2015: 414-29.

${ }^{65}$ Gao Kai, Peng Liyuan aige youshui qianming huyu weiyuan guanhuai aizi zhi gu'ertong (Peng Liyuan lobbies delegates one by one for signatures regarding an appeal on caring for children orphaned by AIDS), Zhongguo xinwenwang (China news service), 6 March 2008, http://www.chinanews.com/yl/mxzz/news/2008/0306/1184522.shtml, accessed 28 October 2015; Xie Qishan et al., She ‘xinli daoshi’ bang shaonian jie wangyin (To arrange 'psychological tutors' to help rehabilitate teenagers addicted to the Internet), Guangzhou ribao (Guangzhou daily), 11 March 2007, 2; and Zhengfu ying yi duozhong xingshi shouyang aizibing ertong (The government should adopt multiple methods to care for children with AIDS), Beijing qingnianbao (Beijing youth daily), 10 March 2008, http://www.aids.org.cn/cms/aidslist/info?id=2652, accessed 13 November 2015.

${ }^{66}$ Meng Lingsheng and Lü Donghao, Yang Lan weiyuan: Yindao jiuye guannian xiang shehui zuzhi fangxiang zhuanbian (Delegate Yang Lan: Changing perceptions on employment in social organizations), Renmin zhengxiebao (People's political consultative daily), 6 March 2009, D01; Xiao Huanhuan, Weiyuan reyi Guo Meimei shijian: Yang Lan ti'an jianyi jinkuai cishan lifa (Delegates heatedly discuss the Guo Meimei incident: Yang Lan proposes making appropriate legislation as soon as possible), 5 March 2012, http://gongyi.qq.com/a/20120305/000001.htm, accessed 2 June 2015; and Zhao Guangxia, Yang Lan ti'an: Guanzhu liudong qingshaonian zhiye jiaoyu wenti (Yang Lan's proposal: Pay attention to problems of vocational training for children of rural-to-urban migrant workers), 6 March 2011, http://2011lianghui.people.com.cn/GB/214394/14072624.html, accessed 2 June 2015.

${ }^{67}$ Liang Daijie, Ertong fulifa heshi chutai (When will a child welfare law be enacted?), Beijing ribao (Beijing daily), 16 January 2013, 18; Meng Yonghui, Han Hong weiyuan: Aiguozhuyi jiaoyu yao cong wawa zhuaqi! (Delegate Han Hong: Patriotic education should start with children!), Guoji zaixian (China radio international online), 4 March 2008, http://gb.cri.cn/18824/2008/03/04/106\%401964930.htm, accessed 29 October 2015; Wei Minli, Shi Jingnan, and Huang Xiaoxi, Minzhengbu guanzhu baohu kunjing ertong de ti'an (Ministry of Civil Affairs proposal on protecting children in difficult circumstances), Xinhua meiri dianxun (Xinhua daily telegraph), 5 March 2011, 2; and Yu Bin, Yu Xiaojie, and Shi Jingnan, Han Hong weiyuan: Ying rang kunjing zhong de haizi you zunyan (Delegate Han Hong: Give children in difficult circumstances dignity), Xinhua meiri dianxun (Xinhua daily telegraph), 2 March 2011, 4.

${ }^{68}$ Personal communication with a CPPCC delegate, December 2014.

${ }^{69}$ Guanyu jiazheng fuwu shichang jixu guifan de ti'an (Proposal on the urgent need to standardize the market for domestic housekeeping services), Zhongguo Renmin Zhengzhi Xieshanghui Quanguo weiyuanhui (The 
National Committee of the Chinese People's Political Consultative Conference), 24 February 2012, http://www.cppcc.gov.cn/zxww/2012/02/24/ARTI1330049640449323.shtml, accessed 4 March 2015.

${ }^{70}$ Chen Yuanyuan, Minjian huanbao ti' an ruhe shang 'lianghui' (How to get environmental proposals from the non-governmental sector presented at the 'two meetings' [NPC and CPPCC]), Zhongguo huanjingbao (China environment news), 7 March 2012, 3.

${ }^{71}$ Guanyu guanzhu qingshaonian wenhua chanpin de kaifa de ti'an (Proposal on paying attention to the development of cultural products for youth), Zhongguo Renmin Zhengzhi Xieshanghui Quanguo weiyuanhui (The National Committee of the Chinese People's Political Consultative Conference), 24 February 2012, http://www.cppcc.gov.cn/zxww/2012/02/24/ARTI1330050198152243.shtml, accessed 4 March 2015.

${ }^{72}$ Guanyu hongyang chuantong wenhua, tigao minzu suzhi, chuantong wenhua jiaoyu xuntao yao cong wawa zhuaqi de ti'an (Proposal on promoting traditional culture and improving the quality of Chinese nationals: The influence of traditional cultural education should start with children), Renminwang (People.com), 25 April 2008, http://cppcc.people.com.cn/GB/34961/121130/121134/7167594.html, accessed 13 November 2015.

${ }^{73}$ Chen Yuanyuan, Minjian huanbao ti'an ruhe shang 'lianghui'.

${ }^{74}$ Zhao Xuemin, Jinkuai luoshi jianli Zhongguo shufaguan (Establish a Chinese calligraphy museum as soon as possible), Zhongguo yishubao (China art news), 9 March 2011, 5.

${ }^{75}$ Guanyu jiaqiang keyan chengguo guanli he liyong de ti'an (Proposal on strengthening the management and use of scientific research achievements), Zhongguo zhengxie xinwenwang (Chinese People's Political Consultative Conference News Network), 13 March 2012, http://cppcc.people.com.cn/GB/34961/238520/240646/17370850.html, accessed 4 March 2015.

${ }^{76} \mathrm{He}$ Yue, Liu Zhengxie weiyuan qi hu dianyingpiao jiangjia (Six delegates at the Chinese People's Political Consultative Conference appeal to reduce the price of cinema tickets), Zhonghua gongshang shibao (China business times), 9 March 2012, E02.

${ }^{77}$ Huang Hai, Zhongxiaochengshi yingyuan jianshe jiasu (Accelerate the construction of cinemas in medium and small cities), Zhongguo wenhuabao (China culture daily), 20 March 2010, 6.

${ }^{78}$ Pei Lei, Cong 'fantizi ti'an' shuokaiqu (Starting the discussion from the 'proposal on traditional characters'), Sichuan ribao (Sichuan daily), 21 March 2008, C04.

${ }^{79} \mathrm{Li}$ Hairuo, Yachang Wan Jie 'lianghui' zai fasheng (Artron's Wan Jie speaks again at the 'two meetings' [NPC and CPPCC]), Jingbao (Shenzhen news), 12 March 2012, B04.

${ }^{80}$ Elaine Jeffreys with Haiqing Yu, Sex in China, Cambridge: Polity Press, 2015, 164.

${ }^{81}$ Li Yinhe de boke (Li Yinhe's blog), http://blog.sina.com.cn/liyinhe, accessed 13 November 2015.

${ }^{82}$ Ouyang Chunyan, Li Yinhe yu dijiao tongxinghunyin hefahua ti'an: Wu daibiao bangmang (Li Yinhe wanted to submit a proposal to legalize same-sex marriage: No delegate would help her), Changsha ribao (Changsha daily), 20 March 2012, http://www.chinanews.com/cul/2012/03-20/3756327.shtml, accessed 13 November 2015. ${ }^{83} \mathrm{Li}$ Yinhe, Zhengji yuanyi dijiao tongxing hunyin ti'an de Renda daibiao (Recruiting delegates from the NPC who are willing to submit the same-sex marriage proposal), 3 March 2012, http://liyinheblog.blog.sohu.com/205905441.html, accessed 4 March 2015.

${ }^{84}$ Elaine Jeffreys, Prostitution Scandals in China: Policing, Media and Society, London and New York: Routledge, 2012, 130. 
${ }^{85} \mathrm{Ibid}$

${ }^{86}$ Huang Wei, Li Yinhe: Bei 'guoxie' jinqu de doushi (Li Yinhe: A coerced warrior), Zhongguo xinwen zhoukan (China newsweek), no. 48, 2009: 144-7; Li Tie, Tongxin hunyin, Li Yinhe xiangde tai jiandan (Li Yinhe's position on same-sex marriage is too naive), Shidai zhoubao (Time weekly), no. 62, 2010, http://www.timeweekly.com/story/2010-01-20/105485.html, accessed 11 November 2015; and Li Yinhe, Tongxing hunyin ti'an (Same-sex marriage proposal), 26 January 2007, http://blog.sina.com.cn/s/blog_473d5336010007t1.html\#comment1, accessed 4 March 2015.

${ }^{87}$ Ouyang, Li Yinhe yu dijiao tongxinghunyin hefahua ti'an.

${ }^{88}$ Kapoor, Celebrity Humanitarianism.

\section{References}

About us [China Entrepreneur Club] (n.d.) http://www.daonong.com/English/cec_about.html, accessed 9 November 2015.

Alxa SEE Ecological Association (n.d.) China CSR Map.

http://www.chinacsrmap.org/Org_Show_EN.asp?ID=209, accessed 4 March 2015.

Angelina Jolie Pitt: a special envoy for refugee issues, UNHCR, http://www.unhcr.org/pages/49c3646c56.html, accessed 9 November 2015.

As it happened: Barack Obama defeats Mitt Romney to win second term as US president (2012) News.com.au, 7 November. http://www.news.com.au/world/live-barack-obama-mitt-romney-in-final-stretch-of-election-

2012/story-fndir2ev-1226511582131, accessed 9 November 2015.

Backgrounder: NPC motions and CPPCC proposals (2015) China Daily, 2 February.

http://www.chinadaily.com.cn/china/2015twosession/2015-03/02/content_19696372.htm, accessed 9 November 2015.

Bai jia jigou zai Beijing lianhe changyi 'nianfan ling yuchi' (100 organizations launch a 'No shark-fin soup for New Year banquets' initiative in Beijing) (2011) Tencent, 23 December.

http://news.qq.com/a/20111223/000533.htm, accessed 2 June 2015.

Barboza, David (2011) China leader encourages criticism of government. The New York Times, 26 January, A9.

Bo Xilai [biography] (n.d.) http://chinavitae.com/biography/Bo_Xilai/full, accessed 4 March 2015. 
Cartier, Carolyn and Tomba, Luigi (2012) Symbolic cities and the 'cake debate'. In: Barmé, Geremie R. (ed.) China Story Yearbook 2012: Red Rising, Red Eclipse. Canberra: Australian Centre on China in the World, 2652.

Chen, Minglu (2015) From economic elites to political elites: Private entrepreneurs in the People's Political Consultative Conference. Journal of Contemporary China 24(94): 613-27.

Chen, Yuanyuan (2012) Minjian huanbao ti'an ruhe shang 'lianghui' (How to get environmental proposals from the non-governmental sector presented at the 'two meetings' [NPC and CPPCC]). Zhongguo huanjingbao (China environment news), 7 March, 3.

Chen, Zhao, Lu, Ming, and He, Junzhi (2008) Power and political participation of entrepreneurs: Evidence from Liuzhou, Guangxi, China. Journal of the Asia Pacific Economy 13(3): 298-312.

China communist party to probe Wen family wealth: SCMP (2012) Reuters, 4 November. http://www.reuters.com/article/2012/11/05/us-china-wen-wealthidUSBRE8A402I20121105\#aJIS3ulTCvv6Fulg.99, accessed 9 November 2015.

Cohen, David (2013) Xi Jinping: China’s first social media president? The Diplomat, 8 January. http://thediplomat.com/2013/01/xi-jinping-chinas-first-social-media-president/, accessed 9 November 2015.

Cooper, Andrew F. (2008) Celebrity Diplomacy. Boulder CO: Paradigm Publishers.

Cowen, Tyler (2000) What Price Fame? Cambridge, MA: Harvard University Press.

Daibiao mingdan (List of delegates) (n.d.) Quanguo Renmin Daibiao Dahui (The National People's Congress of the People's Republic of China). http://www.npc.gov.cn/delegate/delegateArea.action, accessed 1 June 2015.

Duan, Zelin (2011) Dilina'er Abudula daibiao: Jianyi tigao wenhua congye renyuan daiyu (Delegate Dilina'er Abudula: Recommends improving the treatment of professionals in the culture industry). Zhongguo yishubao (China art news), 11 March, http://www.cflac.org.cn/zt/2011-03/11/content_22260295.htm, accessed 10 November 2015.

Edwards, Louise and Jeffreys, Elaine (2010) Celebrity in China. Hong Kong: Hong Kong University Press.

Evans, Michael (2012) Yao Ming is China's newest popular, controversial celebrity politician. Asian Correspondent, 28 January. http://asiancorrespondent.com/74757/yao-ming-is-chinas-newest-popularcontroversial-celebrity-politician/, accessed 26 October 2015. 
Gao, Kai (2008) Peng Liyuan aige youshui qianming huyu weiyuan guanhuai aizi zhi gu'ertong (Peng Liyuan lobbies delegates one by one for signatures for an appeal on caring for children orphaned by AIDS). Zhongguo xinwenwang (China news service), 6 March. http://www.chinanews.com/yl/mxzz/news/2008/0306/1184522.shtml, accessed 28 October 2015.

Garthwaite, Craig and Moore, Tim (2008) The role of celebrity endorsements in politics: Oprah, Obama, and the 2008 Democratic Primary. August.

http://www.stat.columbia.edu/ gelman/stuff_for_blog/celebrityendorsements_garthwaitemoore.pdf, accessed 13 November 2015.

Going down fighting: China has been gripped by an extraordinary courtroom drama (2013) The Economist, 31 August. http://www.economist.com/news/china/21584367-china-has-been-gripped-extraordinary-courtroomdrama-going-down-fighting, accessed 2 June 2015.

Goodman, David S. G. (2014) Class in Contemporary China. Cambridge: Polity Press.

Guanyu guanzhu qingshaonian wenhuachanpin de kaifa de ti'an (Proposal on paying attention to the development of cultural products for youth) (2012) Zhongguo Renmin Zhengzhi Xieshanghui Quanguo weiyuanhui (The National Committee of the Chinese People's Political Consultative Conference), 24 February. http://www.cppcc.gov.cn/zxww/2012/02/24/ARTI1330050198152243.shtml, accessed 4 March 2015.

Guanyu hongyang chuantong wenhua, tigao minzu suzhi, chuantong wenhua jiaoyu xuntao yao cong wawa zhuaqi de ti'an (Proposal on promoting traditional culture and improving the quality of Chinese nationals: The influence of traditional cultural education should start with children) (2008) Renminwang (People.com), 25 April. http://cppcc.people.com.cn/GB/34961/121130/121134/7167594.html, accessed 4 March 2015.

Guanyu jiaqiang keyan chengguo guanli he liyong de ti'an (Proposal on strengthening the management and use of scientific research achievements) (2012) Zhongguo zhengxie xinwenwang (Chinese People's Political Consultative Conference News Network), 13 March. http://cppcc.people.com.cn/GB/34961/238520/240646/17370850.html, accessed 4 March 2015.

Guanyu jiazheng fuwu shichang jixu guifan de ti'an (Proposal on the urgent need to standardize the market for domestic housekeeping services) (2012) 24 February. http://www.cppcc.gov.cn/zxww/2012/02/24/ARTI1330049640449323.shtml, accessed 4 March 2015.

Han Hong: Wo you 200 duo ge gu'er, Zhongguo jiaoyu zhuangkuang yipian dahao (Han Hong: I support more than 200 orphans, China's education system is excellent) (2010) 4 March. http://news.163.com/10/0304/20/60V7CL1J000146BC.html, accessed 4 March 2015. 
He, Yue (2012) Liu Zhengxie weiyuan qi hu dianyingpiao jiangjia (Six delegates at the Chinese People's Political Consultative Conference appeal to reduce the price of cinema tickets). Zhonghua gongshang shibao (China business times), 9 March, E02.

Hood, Johanna (2015) Peng Liyuan's humanitarianism: morality, politics and eyeing the present and past, Celebrity Studies 6 (4): 414-29.

Huang, Hai (2010) Zhongxiaochengshi yingyuan jianshe jiasu (Accelerate the construction of cinemas in medium and small cities). Zhongguo wenhuabao (China culture daily), 20 March, 6.

Huang, Wei (2009) Li Yinhe: Bei 'guoxie' jinqu de doushi (Li Yinhe: A coerced warrior). Zhongguo xinwen zhoukan (China newsweek), no. 48: 144-7.

Jeffreys, Elaine (2012) Prostitution Scandals in China: Policing, Media and Society. London and New York: Routledge.

Jeffreys, Elaine with Yu, Haiqing (2015) Sex in China. Cambridge: Polity Press.

Jiang, Yekui (2005) Zhongguo mingxing guanyuan de shidai tezheng (The distinctive features of contemporary Chinese celebrity officials). 15 July. http://finance.sina.com.cn/review/20050715/10391800522.shtml, accessed 1 June 2015.

Kapoor, Ilan (2013) Celebrity Humanitarianism: The Ideology of Global Charity. London and New York: Routledge.

Kellner, Douglas (2010) Celebrity diplomacy, spectacle and Barack Obama. Celebrity Studies 1(1): 121-3.

Li, Hairuo (2012) Yachang Wan Jie 'lianghui' zai fasheng (Artron's Wan Jie speaks again at the 'two meetings' [NPC and CPPCC]). Jingbao (Shenzhen daily), 12 March, B04.

$\mathrm{Li}$, Tie (2010) Tongxin hunyin Li Yinhe xiangde tai jiandan (Li Yinhe's position on same-sex marriage is too naive). Shidai zhoubao (Time weekly), no. 62, http://www.time-weekly.com/story/2010-01-20/105485.html, accessed 11 November 2015.

Li Yinhe (blog) (2007) Tongxing hunyin ti'an (Same-sex marriage proposal). 26 January. http://blog.sina.com.cn/s/blog_473d5336010007t1.html\#comment1, accessed 4 March 2015. 
Li Yinhe (blog) (2012) Zhengji yuanyi dijiao tongxing hunyin ti'an de Renda daibiao (Recruiting delegates from the NPC who are willing to submit the same-sex marriage proposal). 3 March.

http://liyinheblog.blog.sohu.com/205905441.html, accessed 4 March 2015.

Li Yinhe de boke (Li Yinhe’s blog) (n.d.) http://blog.sina.com.cn/liyinhe, accessed 13 November 2015.

Liang, Daijie (2013) Ertong fulifa heshi chutai (When will a child welfare law be enacted?). Beijing ribao (Beijing daily), 16 January, 18.

Lu, Rachel (2012) Weibo reaction to Wen Jiabao's corruption. Foreign Policy, 26 October,

http://foreignpolicy.com/2012/10/26/weibo-reaction-to-wen-jiabaos-corruption/), accessed 10 November 2015.

Marsh, David, 't Hart, Paul, and Tindall, Karen (2010) Celebrity politics: The politics of the late modernity?

Political Studies Review 8(3): 322-40.

Meng, Lingsheng and Lü, Donghao (2009) Yang Lan weiyuan: Yindao jiuye guannian xiang shehuizuzhi fangxiang zhuanbian (Delegate Yang Lan: Changing perceptions on employment in social organizations). Renmin zhengxiebao (People's political consultative daily), 6 March, D01.

Meng, Yonghui (2008) Han Hong weiyuan: Aiguozhuyi jiaoyu yao cong wawa zhuaqi! (Delegate Han Hong: Patriotic education should start with children!). Guoji zaixian (China radio international online), 4 March. http://gb.cri.cn/18824/2008/03/04/106\%401964930.htm, accessed 29 October 2015.

Malcolm Moore and Philip Sherwell, Crouching Tiger star fights claims she was one of Bo's '100 mistresses', The Age, 30 September 2012, http://www.theage.com.au/world/crouching-tiger-star-fights-claims-she-was-oneof-bos-100-mistresses-20120930-26t49.html?skin=text-only, accessed 10 November 2015.

Ouyang, Chunyan (2012) Li Yinhe yu dijiao tongxinghunyin hefahua ti'an: Wu daibiao bangmang (Li Yinhe wanted to submit a proposal to legalize same-sex marriage: No delegate would help her). 20 March. http://www.chinanews.com/cul/2012/03-20/3756327.shtml, accessed 13 November 2015.

Pan, Wen (2010) Yong guan'ai chengqi yipian qingkong (Hold up a clear sky with love). Renmin ribao (People's daily), 28 April, 20.

Pei, Lei (2008) Cong 'fantizi ti'an' shuokaiqu (Starting the discussion from the 'proposal on traditional characters'). Sichuan ribao (Sichuan daily), 21 March, C04. 
Phillips, Tom (2014) Xi Jinping: The growing cult of China's 'Big Daddy Xi'. The Telegraph, 8 December, http://www.telegraph.co.uk/news/worldnews/asia/china/11279204/Xi-Jinping-the-growing-cult-of-Chinas-BigDaddy-Xi.html, accessed 10 November 2015.

Shipin: Yesheng Jiuyuan gongyi guanggao (Video: WildAid public service announcement) (2012) Youku, http://v.youku.com/v_show/id_XNTIzNDU3NzQ4.html, accessed 4 March 2015.

Shouquan fabu: Zhonghua Renmin Gongheguo guomin jingji he shehui fazhan di shiyi ge wunian guihua gangyao (quanwen) (Authorized release: PRC's 11th Five-Year Plan for national economic and social development (full text)) (2006) http://news.xinhuanet.com/misc/2006-03/16/content_4309517.htm, accessed 4 March 2015.

Sudworth, John (2013) Chinese court rejects Bo Xilai appeal and upholds life sentence. BBC News China, 25 October. http://www.bbc.com/news/world-asia-china-24652525, accessed 10 November 2015.

Tan Jing yu wei Zhongguo zhiyuanzhe lifa: Yin kan dao tamen de weida ke'ai (Tan Jing calls for volunteer legislation: Because she saw how great and lovely they are) (2012) 6 March. http://www.chinanews.com/yl/2012/03-06/3721792.shtml, accessed 4 March 2015.

The 400 richest Chinese: \#140 Liguo Ding \& family (2008) Forbes, 29 October. http://www.forbes.com/lists/2008/74/chinarichest08_Liguo-Ding-family_9S0Y.html, accessed 17 March 2015.

Ti'an ji ban fu xuandeng (Selected proposals and responses) (n.d.) Zhongguo Renmin Zhengzhi Xieshang Huiyi Quanguo weiyuanhui (The National Committee of the Chinese People's Political Consultative Conference). http://www.cppcc.gov.cn/zxww/zxww/tajbfxd/index.shtml, accessed 4 March 2015.

The National People's Congress: What makes a rubber stamp? (2012) The Economist, 5 March. http://www.economist.com/blogs/analects/2012/03/national-peoples-congress, accessed 10 November 2015.

Truex, Rory (2014) The returns to office in a 'rubber stamp' parliament. American Political Science Review 108(2): 235-51.

Tsaliki, Liza, Frangonikolopoulos, Christos A., and Huliaras, Asteris (eds) (2011) Transnational Celebrity Activism in Global Politics: Changing the World? Bristol and Chicago: Intellect Press.

Turner, Graeme (2004) Understanding Celebrity. London: Sage.

Van Zoonen, Liesbet (2006) The personal, the political and the popular: A woman's guide to celebrity politics. European Journal of Cultural Studies 9(3): 287-301. 
Wang, Yongsheng (2012) Gong'anbu: Yi zhuoshou xiugai jiazhao guifan (Ministry of Public Security: Modifying regulations regarding drivers' licences). Fazhi wanbao (The mirror), 8 January, A11.

Wang, Zheng (2013) The Bo Xilai verdict: Everybody wins. The Diplomat, 22 September.

http://thediplomat.com/2013/09/the-bo-xilai-verdict-everybody-wins/, accessed 10 November 2015.

Wei, Minli, Shi, Jingnan, and Huang, Xiaoxi (2011) Minzhengbu guanzhu baohu kunjing ertong de ti'an (Ministry of Civil Affairs proposal on protecting children in difficult circumstances). Xinhua meiri dianxun (Xinhua daily telegraph), 5 March, 2.

Weiskel, Timothy (2005) From sidekick to sideshow - Celebrity, entertainment, and the politics of distraction: Why Americans are 'sleepwalking towards the end of the earth'. American Behavioral Scientists 49(3): 393-409.

West, Darrell M. and Orman, John (2003) Celebrity Politics. Upper Saddle River NJ: Prentice Hall.

WildAid PSA - Yao Ming: Shark fin soup (2009) Youtube, 15 December.

http://www.youtube.com/watch?v=mJG7RaLX-DM\&feature=relmfu, accessed 4 March 2015

WildAid PSA - Yao Ming: The price of shark fin soup (2011) Youtube, 29 September.

http://www.youtube.com/watch?v=G7oaTCBuI2g, accessed 4 March 2015.

WildAid (n.d.) Sharks. http://www.wildaid.org/sharks, accessed 4 March 2015.

Wu, J. R. and Dean, Jason (2010) Wen engages web users in rare chat: Chinese Premier, reflecting government's growing Internet use, addresses economy, U.S. ties, but avoids politics. The Wall Street Journal, 1 March. http://www.wsj.com/articles/SB10001424052748704089904575093102225297546, accessed 9 November 2015.

Wu, Wei, and Luo, Jing (2011) Lei Ayouduo: Fazhan minzu wenhua lüyou chanye tigao xingfu gan (Lei Ayouduo: Develop the ethnic minority culture tourism industry and promote happiness). Tencent, 4 March. http://news.qq.com/a/20110304/002342.htm, accessed 2 June 2015.

Xiao, Huanhuan (2012) Weiyuan reyi Guo Meimei shijian: Yang Lan ti'an jianyi jinkuai cishan lifa (Delegates heatedly discuss the Guo Meimei incident: Yang Lan proposes making appropriate legislation as soon as possible). 5 March. http://gongyi.qq.com/a/20120305/000001.htm, accessed 2 June 2015.

Xie, Qishan et al. (2007) She 'xinli daoshi' bang shaonian jie wangyin (To arrange 'psychological tutors' to help rehabilitate teenagers addicted to the Internet). Guangzhou ribao (Guangzhou daily), 11 March, 2. 
Xu Yiqing (n.d.) Cunzhuang xuanju gei Zhongguo nongcun dai laile shenme? Wenxian zongshu ji yixie xin de zhengju (What do Chinese village elections bring? A literature review and some new evidence), Beijing daxue Zhongguo jingji yanjiu zhongxin (China Center for Economic Research, Peking University), http://www.mit.edu/ xyq/papers/chinese/Xu_electionreview.pdf, accessed 13 November 2015.

Yang, Xiaohong (2012) Shenzhen, Zhongguo shou ge 'ling yuchi chengshi' husheng zuigao? (Shenzhen: The loudest voice for the first 'zero shark-fin city' in China?). Nanfang dushibao (Southern metropolis daily), 26 July. http://gongyi.oeeee.com/ndgyzk/201206/t20120604_1310212.html, accessed 9 November 2015.

Yu, Bin, Yu, Xiaojie, and Shi, Jingnan (2011) Han Hong weiyuan: Ying rang kunjing zhong de haizi you zunyan (Delegate Han Hong: Give children in difficult circumstances dignity). Xinhua meiri dianxun (Xinhua daily telegraph), 2 March, 4.

Yu, Jie (2010) Zhongguo yingdi Wen Jiabao (China's best actor: Wen Jiabao). Hong Kong: New Century Press.

Yu, Wenjun (2012) Daibiao weiyuan xu yongxin lü zhi (NPC delegates should fulfil their duties). Xibu shangbao (Western daily), 5 March, http://www.xbsb.com.cn/xbsbnews/hhpl/hhpl/2012-03-05/208521.html, accessed 10 November 2015.

Yuan, Jiansheng (2012) 'Jinshi yuchi': Lifa de shangjie liliang ('Ban the eating of shark fin': The power of the business community to make legislation). 25 July. http://www.daonong.com/g/17/tianxia/2012/0725/34647.html, accessed 2 June 2015.

Zakaria, Fareed (2010) Interview with Wen Jiabao, CNN, 3 October, http://edition.cnn.com/TRANSCRIPTS/1010/03/fzgps.01.html, accessed 9 November 2015.

Zhang, Yumei (2010) Bie rang shufa jiaoyu 'liubianzou' (Don't let calligraphy education 'slide'). Guangming ribao (Guangming daily), 24 November, 1.

Zhao, Guangxia (2011) Yang Lan ti'an: Guanzhu liudong qingshaonian zhiye jiaoyu wenti (Yang Lan's proposal: Pay attention to problems of vocational training for children of rural-to-urban migrant workers). 6 March. http://2011lianghui.people.com.cn/GB/214394/14072624.html, accessed 2 June 2015.

Zhao, Renwei and Gao, Peng (2012) Quanguo Renda daibiao Yang Yang: Zhong xiaoxuesheng meitian duanlian yi xiaoshi bu luoshi ying wen ze xiaozhang (NPC delegate Yang Yang: Principals should be made accountable for not implementing the daily one-hour physical exercise for primary and secondary school students). Xinhua, 8 March. http://www.bj.xinhuanet.com/bjpd-zhuanti/2012-03/08/content_24853643.htm, accessed 2 June 2015 . 
Zhao, Xuemin (2011) Jinkuai luoshi jianli Zhongguo shufaguan (Establish a Chinese calligraphy museum as soon as possible). Zhongguo yishubao (China art news), 9 March, 5.

Zhengfu ying yi duozhong xingshi shouyang aizibing ertong (The government should adopt multiple methods to care for children with AIDS) (2008) Beijing qingnianbao (Beijing youth daily), 10 March, http://www.aids.org.cn/cms/aidslist/info?id=2652, accessed 13 November 2015.

Zhonggong Zhongyang Bangongting, Guowuyuan Bangongting yinfa 'Dangzheng jiguan guonei gongwu jiedai guanli guiding' (The General Office of the Central Committee of the Chinese Communist Party and the State Council issue 'Regulations on Domestic Official Hospitality for Party and Government Organs') (2013) 8 December. http://news.xinhuanet.com/politics/2013-12/08/c_118467426.htm, accessed 2 June 2015.

Zhonggong Zhongyang Zhengzhiju zhaokai huiyi, shenyi guanyu gaijin gongzuo zuofeng, miqie lianxi qunzhong de youguan guiding - fenxi yanjiu 2013 nian jingji gongzuo: Zhonggong zhongyang zong shuji Xi Jinping zhuchi huiyi (The Politburo of the Central Committee of the Chinese Communist Party calls for a meeting to discuss relevant regulations on improving work style and public relations - analysis of economic work in 2013: General Secretary Xi Jinping presides over a meeting) (2012) Renmin ribao (People's daily), 5 December, 1 .

Zhonghua Renmin Gongheguo di shiyi jie Quanguo Renmin Daibiao Dahui daibiao mingdan (List of delegates at the 11th National People's Congress of the People's Republic of China) (2008) Renmin ribao (People's daily), 29 February, 2.

Zhonghua Renmin Gongheguo guomin jingji he shehui fazhan di shi ge wunian jihua gangyao (PRC's 10th Five-Year Plan for national economic and social development) (2001) http://www.people.com.cn/GB/historic/0315/5920.html, accessed 13 November 2015.

Zhongguo Renmin Zhengzhi Xieshang Huiyi di shiyi jie Quanguo weiyuanhui weiyuan mingdan (List of delegates at the 11th National Committee of the Chinese People's Political Consultative Conference) (2008) Renmin ribao (People's daily), 26 January, 2.

Zhou, Xiaohua and Wang, Jie (2008) Wan Shanhong weiyuan jianyi: 'Chang guoge' daiti 'zou guoge' (Delegate Wan Shanhong's suggestion: Replace 'playing the national anthem on musical instruments' with 'singing the national anthem'), Changsha wanbao (Changsha evening news), 4 March, http://www.changsha.cn/zt/ztguonei/2008h/16/200803/t20080304_801164.htm, accessed 13 November 2015. 